\title{
Patients with essential blepharospasm and glaucoma: case reports
}

\author{
Pacientes com glaucoma e blefaroespasmo essencial: relato de casos
}

\author{
André Gustavo Bombana Nicoletti ${ }^{1}$ \\ Leandro Cabral Zacharias ${ }^{2}$ \\ RemoSusanna Jr. ${ }^{3}$ \\ Suzana Matayoshi ${ }^{4}$
}

Trabalho realizado na Clínica Oftalmológica do Hospital das Clínicas da FMUSP - São Paulo (SP) - Brasil.

Pós-graduando do Departamento de Plástica Ocular do Hospital das Clínicas da Faculdade de Medicina da Universidade de São Paulo - USP - São Paulo (SP) Brasil.

${ }^{2}$ Vitreous and Retina Clinical Fellow, University of California - Irvine - USA.

${ }^{3}$ Chefe do Departamento de Glaucoma do Hospital das Clínicas da Faculdade de Medicina da USP - São Paulo (SP) - Brasil.

${ }^{4}$ Chefe do Departamento de Plástica Ocular do Hospital das Clínicas da Faculdade de Medicina da USP - São Paulo (SP) - Brasil.

Endereço para correspondência: André G. B. Nicoletti. Rua $1^{\circ}$ de Maio, 184 - Apto. 60 - Santo André (SP)

CEP 09015-030

E-mail: agbnicoletti@yahoo.com.br

A pesquisa foi desenvolvida sem fontes de auxílio.

Recebido para publicação em 07.01.2008

Última versão recebida em 28.05.2008

Aprovação em 04.06.2008

\begin{tabular}{l} 
ABSTRACT \\
\hline Essential blepharospasm is a facial dystonia characterized by sponta- \\
neous, spasmodic and involuntary contractions of the eyelid muscles. \\
In advanced cases, blepharospasm patients develop severe eyelid spasms \\
that render them functionally blind, socially reclusive, and unable to \\
work or care for themselves. Oculoplastic surgeons frequently have to \\
deal with patients with blepharospasm. The decrease in quality of life \\
caused by this pathology drives all the attention to the resolution of the \\
spasms. However, other conditions may be associated with them and \\
must be kept in mind during the ophthalmological examination. Four \\
patients with essential blepharospasm were diagnosed as glaucomatous \\
during their follow-up at the Oculoplastic Service. All of them showed \\
glaucomatous optic neuropathy and corresponding visual field defect \\
and no clinically apparent secondary cause for their glaucoma. Forced \\
eyelid closure may lead to intraocular pressure peaks. These patients \\
with blepharospasm present repetitive and spasmodic eyelid contractions \\
and the intraocular pressure rise observed during eyelid squeezing \\
could be an additional risk factor for glaucomatous damage. Our case \\
series suggest that patients with blepharospasm should be seriously \\
evaluated for glaucoma.
\end{tabular}

Keywords: Eye/physiopathology; Blepharospasm; Glaucoma; Dystonia; Eyelid; Intraocular pressure; Water/diagnostic use; Drinking

\section{INTRODUCTION}

Essential blepharospasm is an adult onset facial dystonia characterized by spontaneous, spasmodic, bilateral, intermittent or persistent involuntary contraction of the entire (pretarsal, preseptal and periorbital) orbicularis muscles. The mean age at onset of benign essential blepharospasm is 56 years. Women outnumber men by $3: 1^{(1)}$.

Most cases present at ophthalmologists, since the initial symptoms of the condition - discomfort, irritation or dryness of the eyes - suggest local ocular disease ${ }^{(2)}$.

Oculoplastic surgeons frequently have to deal with patients with blepharospasm. In advanced cases, blepharospasm patients develop severe eyelid spasms that render them functionally blind, socially reclusive, and unable to work or care for themselves. For this reason, it is not uncommon for the oculoplastic specialist to keep focused on the resolution of the spasms and neglect other simultaneous pathologies. We report 4 cases of blepharospasm associated to advanced glaucoma, diagnosed during follow-up at the Oculoplastic Department. 


\section{CASE REPORTS}

Four white female patients with essential blepharospasm were diagnosed as glaucomatous during their follow-up at the Oculoplastic Department. The mean age of patients was $75.00 \pm 4.55$ years. One patient had hypertension and no patient referred diabetes history. All patients had a negative family history of glaucoma. One patient was submitted to cataract surgery in both eyes.

We performed refractometry and best corrected visual acuity with Snellen chart, slitlamp biomicroscopy (HaagStreit AG, Bern, Switzerland), applanation tonometry (Goldmann; Haag-Streit AG, Liebefeld, Switzerland), gonioscopy, automated perimetry (Humphrey Instruments Inc, H750, Dublin, California/ USA), water drinking test ${ }^{(3-4)}$ and dilated funduscopy to evaluate optic discs. All patients presented optic discs with characteristic signs associated with glaucoma as localized loss of neuroretinal rim tissue, defects of the nerve fiber layer, cup/disc asymmetry and others.

Anderson's criteria ${ }^{(5)}$ were used to define perimetry abnormality: presence of a cluster of three or more nonedge points on the pattern deviation probability map deviating at $p<5 \%$, with one of these points deviating at $\mathrm{p}<1 \%$; pattern standard deviation value occurring in less than $5 \%$ of normal reliable fields $(\mathrm{p}<5 \%)$; or glaucoma hemifield test outside normal limits.
Intraocular pressure (IOP) measurement was always performed after successful botulinum toxin injection. The mean IOP was $20.00 \pm 7.21 \mathrm{mmHg}$. The mean peak of IOP in the water drinking test (WDT) was $24.87 \pm 8.03 \mathrm{mmHg}$. The IOP fluctuation in the WDT was $5.00 \pm 1.77 \mathrm{mmHg}$. All of them showed glaucomatous optic neuropathy, corresponding visual field defect (Figures 1 - 4), open angle and no clinically apparent secondary cause for their glaucoma. No patient had any anterior or posterior segment abnormalities that could interfere with glaucoma diagnosis or IOP measurement. Diagnostic data are summarized in Table 1.

The mean period of blepharospasm diagnosis was 12.25 years. The mean period between blepharospasm diagnosis and the beginning of botulinum toxin treatment was 7.38 years.

\section{DISCUSSION}

Essential blepharospasm is a facial dystonia characterized by spontaneous, spasmodic and involuntary contractions of the eyelid muscles (orbicularis oculi, procerus and corrugator $)^{(1)}$. The majority of patients had ocular symptoms at the onset of their illness such as dryness of the eyes, grittiness, irritation or photophobia suggesting eyelid or ocular surface disease. Ophthalmological complaints were found at onset in $154(57 \%)$ of the 272 patients with blepharospasm ${ }^{(2)}$. Recen-

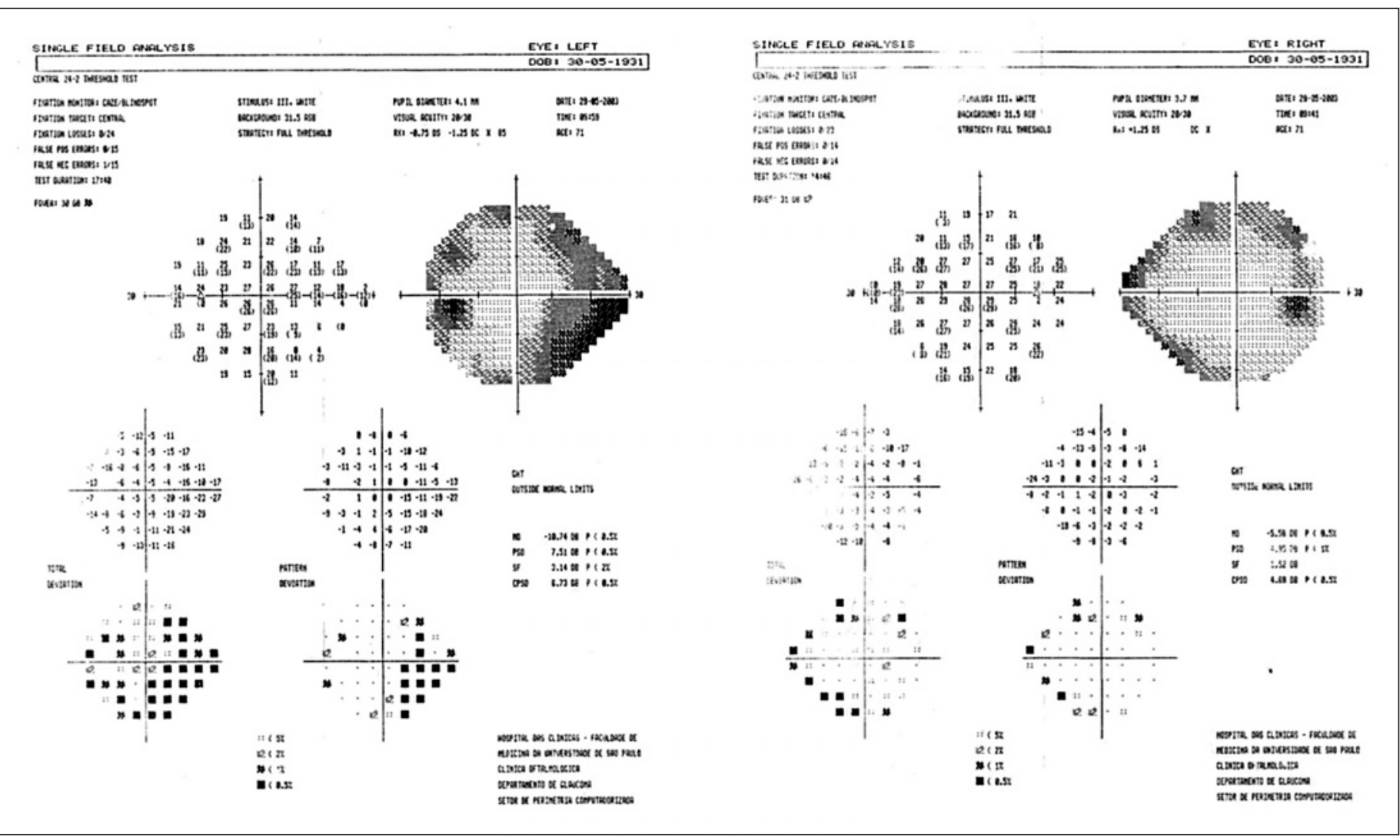

Figure 1 - Patient one visual field defect 


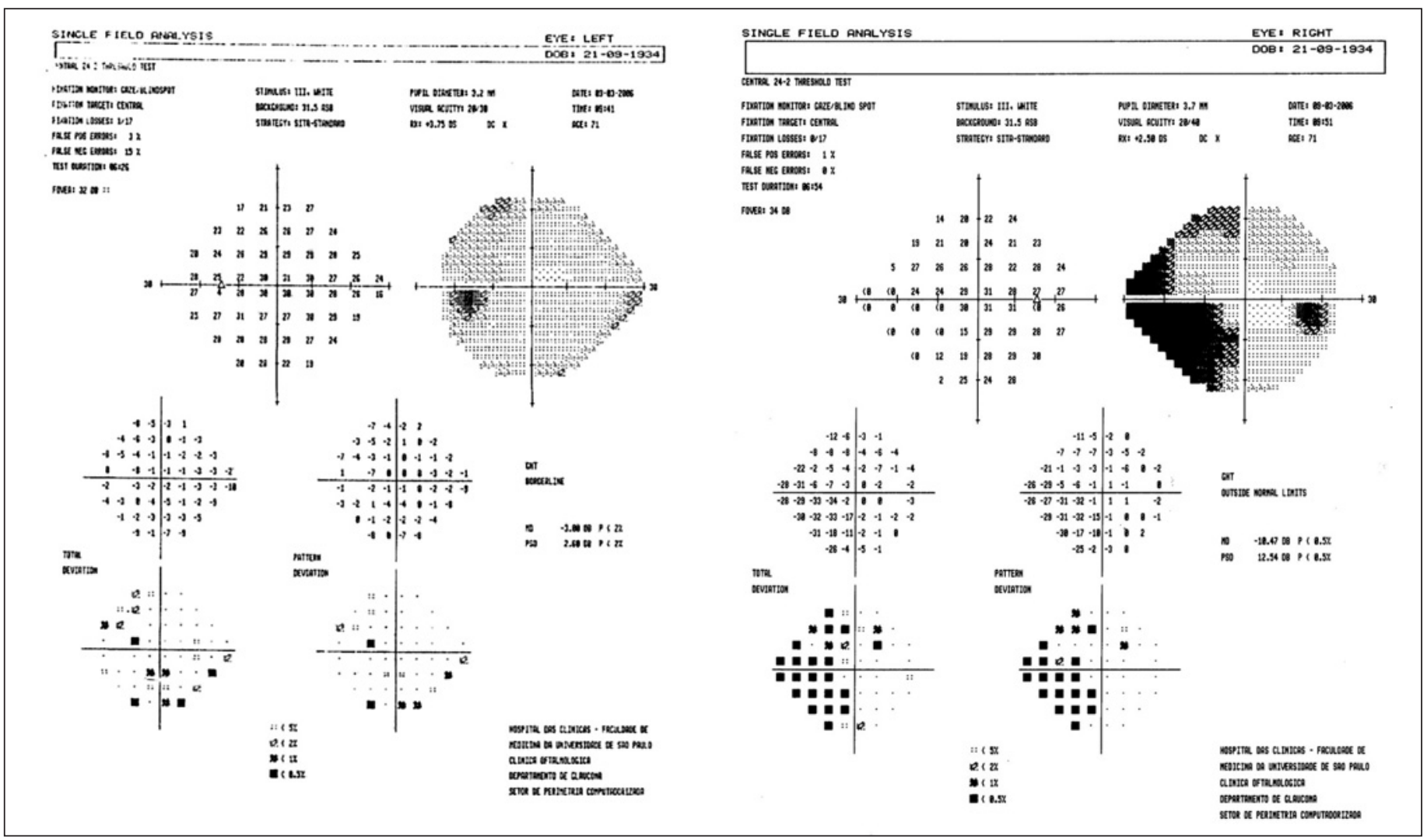

Figure 2 - Patient two visual field defect

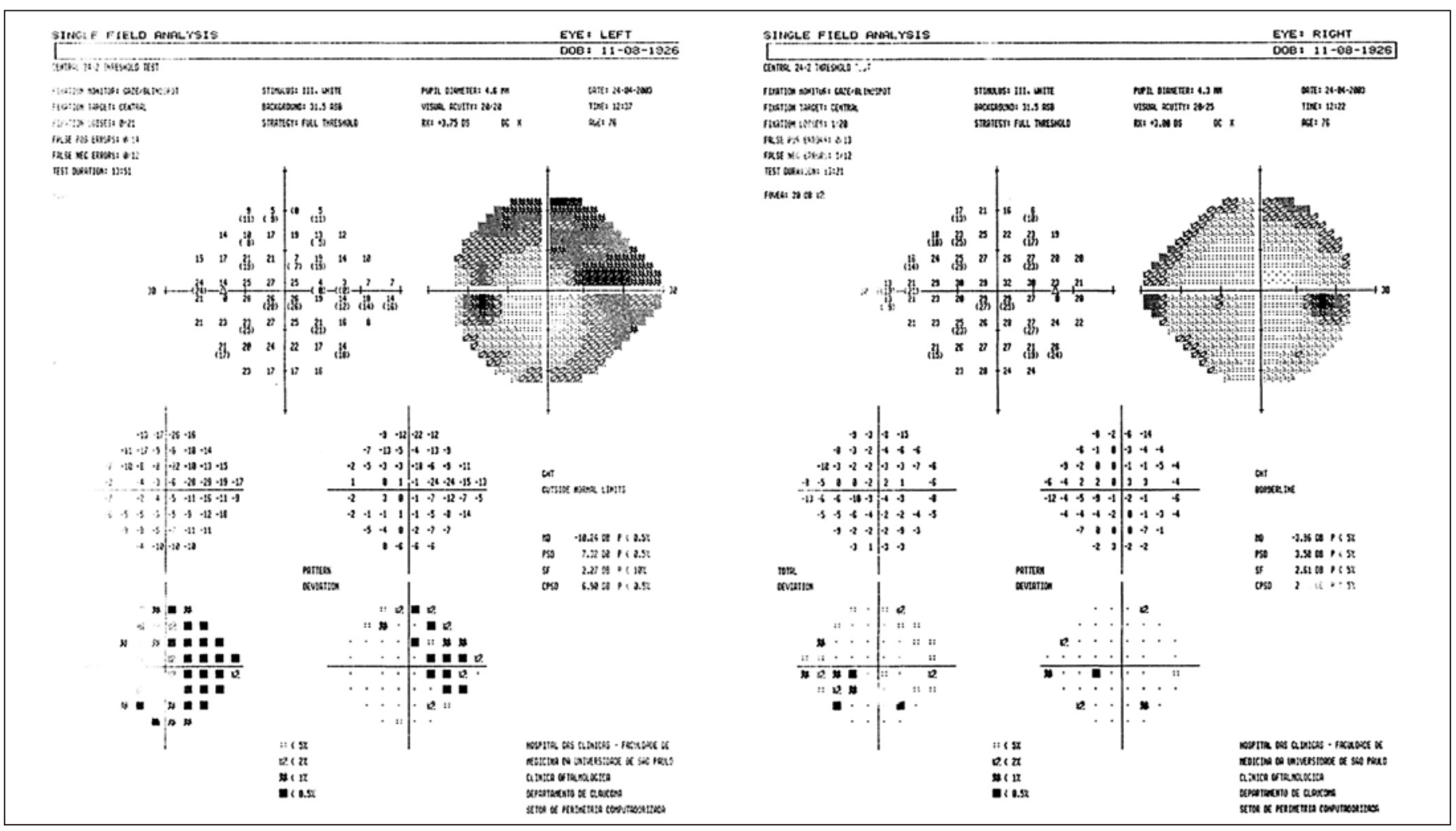

Figure 3 - Patient three visual field defect 


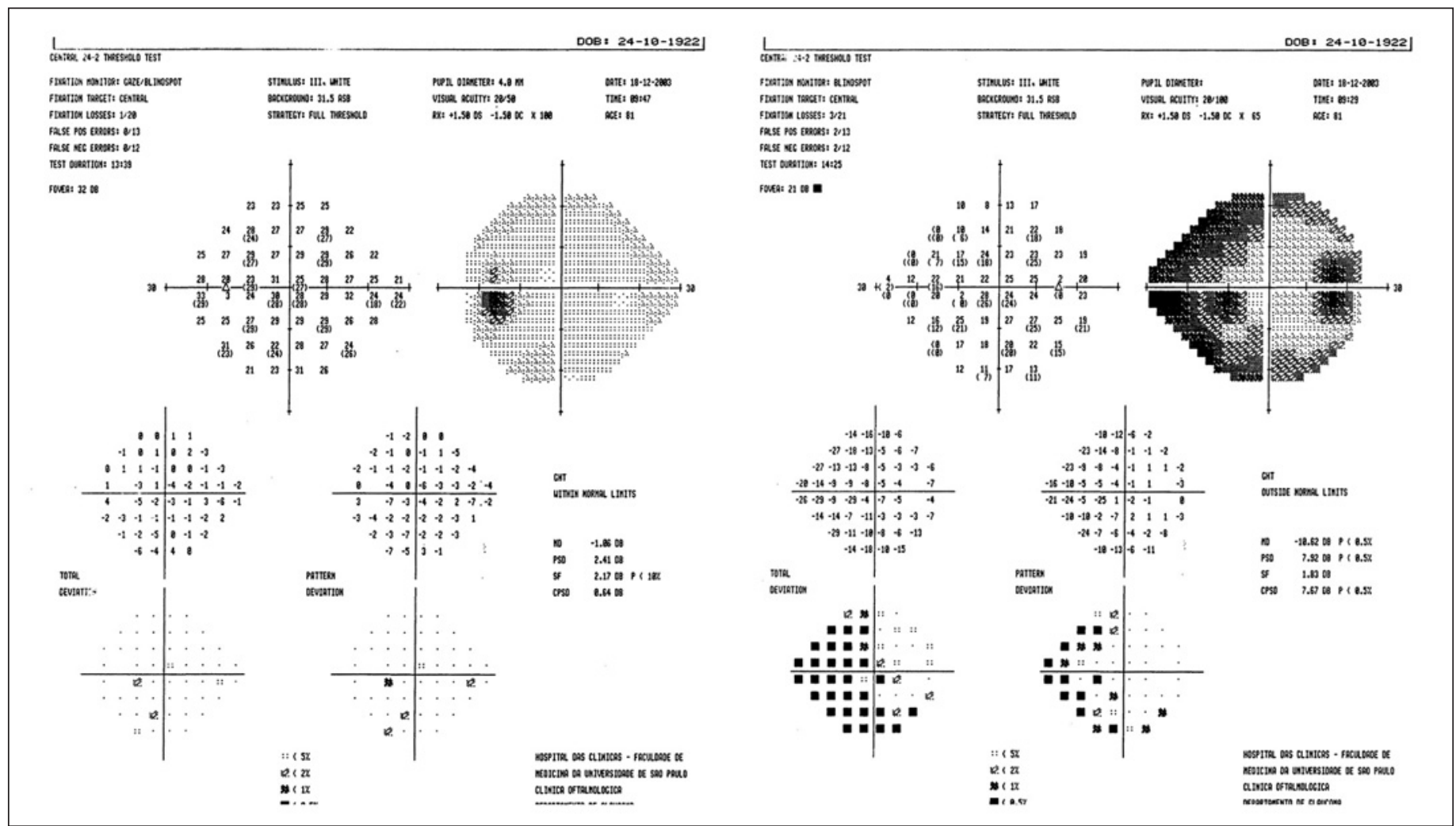

Figure 4 - Patient four visual field defect

\begin{tabular}{|lcc|}
\hline Patient & $\begin{array}{c}\text { Table 1. Diagnostic data of patients reported } \\
\text { IOP } \\
\text { RE / LE } \\
(\mathbf{m m ~ H g})\end{array}$ & $\begin{array}{c}\text { Cup-Disc Ratio } \\
\text { RE vertical } \mathbf{x} \text { horizontal/ } \\
\text { LE vertical } \mathbf{x} \text { horizontal }\end{array}$ \\
1 & $25 / 36$ & $0.7 \times 0.6 / 0.8 \times 0.8$ \\
2 & $18 / 18$ & $0.5 \times 0.5 / 0.8 \times 0.8$ \\
3 & $17 / 15$ & $0.8 \times 0.7 / 0.5 \times 0.4$ \\
4 & $16 / 15$ & $0.8 \times 0.7 / 0.1 \times 0.1$ \\
IOP= Intraocular pressure; $\mathrm{RE}=$ Right eye; LE= Left Eye \\
\hline
\end{tabular}

tly, injection of botulinum toxin has been considered the treatment of choice in patients with blepharospasm ${ }^{(1)}$.

Glaucoma treatment is based on intraocular pressure (IOP) reduction. However, even in situations in which pressure levels are considered within adequate limits, some patients continue to have progressive disease. One possible explanation could be the occurrence of IOP peaks not detected during routine examination. Almost one third of patients with single IOP measurements taken during doctor's office hours had pressure peaks detected only during a 24-hour pressure curve ${ }^{(6)}$.

The WDT presents a good correlation between IOP peaks after water overload and IOP peaks detected during a daily tension curve. This test was also considered a significant risk factor for development of glaucomatous visual field lesion ${ }^{(7)}$. In another study, authors observed that mean IOP peak and IOP variation during WDT were significantly higher in pa- tients with visual field progression compared with patients who did not progress ${ }^{(4)}$.

The influence of eyelid closure in IOP is already known for decades. Using a scleral contact lense-balloon combination attached to a pressure transducer, one author measured the IOP in 10 normal patients during blinking and registered a mean IOP of $10.3 \mathrm{mmHg}$. During eyelid squeezing, the IOP reached up to $51 \mathrm{mmHg}^{(8)}$. The IOP was also studied using an invasive method in a voluntary patient with choroidal melanoma who would be submitted to enucleation ${ }^{(9)}$. Authors detected increases of $10 \mathrm{mmHg}$ in IOP during blinking and levoversion. The IOP reached spikes of up to $110 \mathrm{mmHg}$ during eyelid squeezing.

A previous report described an unilateral glaucoma case in a 75-year-old woman with hemifacial spasm ${ }^{(10)}$. The ipsilateral optic disc showed evident glaucomatous damage whereas the other eye revealed normal findings at examination. During follow-up the IOP was always between 13-14 mmHg in both eyes, except for one measure of $18 \mathrm{mmHg}$. Authors correlated the optic nerve damage to the IOP increases during eyelid squeezing. They also reported that there was no evidence of visual field defect progression or cup disc enlargement during 4 years of follow-up, after the beginning of treatment with botulinum toxin.

It has been hypothesized that the WDT could be used as an indirect tool to measure outflow facility through trabecular meshwork ${ }^{(4)}$. Patient 1 had a high IOP measured in both 
eyes. All other patients had IOP within normal ranges. However, they had a mean peak of $24.87 \pm 8.03 \mathrm{mmHg}$ in the WDT, which could indicate a low outflow easiness. These patients with blepharospasm present repetitive and spasmodic eyelid contractions that would increase IOP several times a day, which could lead to optic nerve damage in patients who have previous low easiness of outflow.

The present study reported four cases of glaucoma in patients with blepharospasm. These findings suggest that oculoplastic specialists must investigate optic nerve damage during presentation and follow-up of this kind of patients. A prospective randomized study is being performed at our Institution to reveal new aspects of this relationship.

\section{RESUMO}

Blefaroespasmo essencial é uma distonia facial caracterizada por contrações espontâneas, espasmódicas e involuntárias dos músculos palpebrais, podendo tornar os pacientes funcionalmente cegos. Tais pacientes são geralmente referidos aos médicos oculoplásticos para avaliação e tratamento. Devido à intensidade dos espasmos e ao comprometimento da qualidade de vida, toda a atenção é dirigida à sua resolução e outras condições oculares associadas podem passar despercebidas. Neste estudo, quatro pacientes com blefaroespasmo foram diagnosticados como glaucomatosos durante o seu seguimento no Departamento de Plástica Ocular. As quatro pacientes apresentavam neuropatia óptica glaucomatosa e defeito no campo visual compatível, sem que houvesse nenhuma causa secundária para o glaucoma. $\mathrm{O}$ fechamento palpebral forçado causa importante aumento da pressão intra-ocular e estes pacientes com blefaroespasmo, por apresentar contrações espasmódicas e repetitivas das pálpebras, poderiam estar sob risco aumentado de desenvolver glaucoma.

Descritores: Olho/fisiopatologia; Blefarospasmo; Glaucoma; Distonia; Pálpebra; Pressão intra-ocular; Água/uso diagnóstico; Ingestão de líquidos

\section{REFERENCES}

1. Roth JA. Inadequate diagnostic value of the water-drinking test. Br J Ophthalmol, 1974;58(1):55-61.

2. Susanna R Jr, Vessani RM, Sakata L, Zacarias LC, Hatanaka M. The relation between intraocular pressure peak in the water drinking test and visual field progression in glaucoma. Br J Ophthalmol. 2005;89(10):1298-301.

3. Anderson D, Patella VM. Automated static perimetry. St Louis: Mosby-Year Book; 1992.

4. Jordan DR, Patrinely JR, Anderson RL, Thiese SM. Essential blepharospasm and related dystonias. Surv Ophthalmol. 1989;34(2):123-32.

5. Elston JS, Marsden CD, Grandas F, Quinn NP. The significance of ophthalmological symptoms in idiopathic blepharospasm. Eye. 1988;2(Pt 4):435-9.

6. Drance SM. Diurnal Variation of intraocular pressure in treated glaucoma. significance in patients with chronic simple glaucoma. Arch Ophthalmol. 1963;70:302-11.

7. Armaly MF, Krueger DE, Maunder L, Becker B, Hetherington J Jr, Kolker AE, et al. Biostatistical analysis of the collaborative glaucoma study. I. Summary report of the risk factors for glaucomatous visual-field defects. Arch Ophthalmol. 1980;98(12):2163-71.

8. Miller D. Pressure of the lid on the eye. Arch Ophthalmol. 1967;78(3):328-30.

9. Coleman DJ, Trokel S. Direct-recorded intraocular pressure variations in a human subject. Arch Ophthalmol. 1969;82(5):637-40.

10. Killer HE, Rust O, Muller O, Flammer J. Unilateral glaucomatous damage in a patient with hemifacial spasm. Ophthalmologica. 1999;213(4):273-5.

\section{ABO Eletrônico}

\section{A versão eletrônica dos Arquivos Brasileiros de Oftalmologia com textos completos está disponível em}

\section{$A B O$ - Arquivos Brasileiros de Oftalmologia http://www.abonet.com.br}

SCIELO - Scientific Electronic Library Online http://www.scielo.org

Free Medical Journals

http://www.freemedicaljournals.com

\section{PubMed}

http://www.pubmed.com

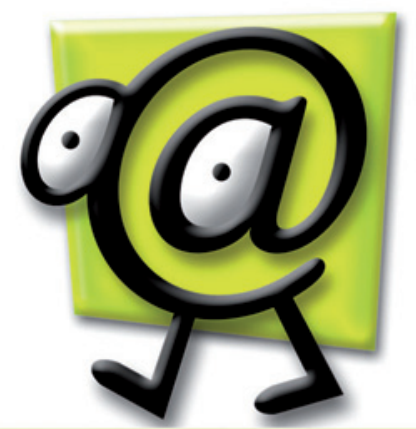

